\title{
Analisis Laporan Keuangan Berdasarkan Psak 109 Yayasan Rumah Yatim Arrohman
}

\author{
Anah Zanatun", Syamsul Hidayat ${ }^{* *}$ dan Nani Rohaeni ${ }^{* * * *}$ \\ *,**, ***Universitas Bina Bangsa, mastersyah@gmail.com, Banten, Indonesia.
}

\section{ARTICLE INFO}

\section{Article history:}

Received 18 Januari 2018

Received I Revised 25

Februari 2019

Accepted xx Februari 2019

Keywords:

Accounting Report, PSAK 109, Zakat.

\section{A B S T R A C T}

The purpose of this study is determine whether the accounting treatment of zakat in Rumah Yatim Arrohman accordance with PSAK No. 109. This research is conducted to examine the financial statements prepared by Rumah Yatim Arrohman accordance with PSAK No. 109 on Accounting for Zakat. The method used is descriptive comparatif approach. The results of this research concluded that Rumah Yatim Mandiri have fully implemented use PSAK No.109. in presenting the financial statements. because in PSAK No. 109, zakah accounting aims to regulate the recognition, measurement, presentation and disclosure of transactions zakah, infaq/ Sadaqah.

Tujuan dari penelitian ini adalah untuk mengetahui apakah perlakuan akuntansi zakat di Rumah Yatim Arrohman sesuai dengan PSAK No. 109. Penelitian ini dilakukan untuk menguji laporan keuangan yang disiapkan Rumah Yatim Arrohman sesuai dengan PSAK No. 109 tentang Akuntansi Zakat. Metode yang digunakan adalah pendekatan deskriptif komparatif. Hasil penelitian ini menyimpulkan bahwa Rumah Yatim Arrohman sebagai salah satu Lembaga Amil Zakat Nasional (LAZNAS) sudah sepenuhnya menerapkan penggunaan PSAK No.109. Dalam menyajikan laporan keuangan. Karena dalam PSAK No. 109, akuntansi zakat bertujuan untuk mengatur pengakuan, pengukuran, penyajian dan pengungkapan transaksi zakat, infaq / sadaqah. 
Peranan penting pasar modal bagi pihak emiten sebagi tempat untuk mendapatkan sumber dana sedangkan bagi investor sebagai tempat untuk menginvestasikan dananya. Bila pasar modal efesien maka pasar modal akan memberikan return seperti yang diharapkan oleh para investor. Investor selalu menginginkan return yang tinggi tetapi selalu menghindari resiko. Akan tetapi, teori menyebutkan bahwa investasi yang mempunyai return tinggi pasti akan mempunyai resiko yang tinggi juga, (Tandelilin, 2010). Dalam menentukan berinvestasi, investor harus mampu menganalisis saham. Melihat saham mana yang menawarkan return dan resiko yang sesuai dengan yang investor inginkan. Investor bisa menilai saham dengan melihat kinerja perusahaannya. Kinerja yang semakin bagus, maka perusahaan itu akan memberikan return yang semakin besar.

Penunaian Zakat merupakan rukun Islam ketiga yang wajib dilaksanakan oleh seorang muslim yang telah memenuhi syarat wajib zakat. Zakat sebenarnya adalah salah satu bentuk sedekah. Zakat merupakan kewajiban bagi setiap muslim yang mampu serta menjadi unsur dari rukun Islam, sedangkan infaq dan shadaqah merupakan wujud kecintaan hamba terhadap nikmat Allah SWT yang telah diberikan kepadanya sehingga seorang hamba rela menyisihkan sebagian hartanya untuk kepentingan agama baik dalam rangka membantu sesama maupun perjuangan dakwah Islam.

Di Indonesia, pengelolaan dana zakat telah diatur berdasarkan Undang-Undang Nomor 38 Tahun 1999 tentang Pengelolaan Zakat. Undang-Undang ini mengatur tentang Organisasi Pengelola Zakat (OPZ) yang boleh beroperasi di Indonesia. Organisasi Pengelola Zakat (OPZ) yang disebut dalam Undang-Undang adalah Badan Amil Zakat (BAZ) dan Lembaga Amil Zakat (LAZ). Badan Amil Zakat (BAZ) merupakan lembaga pengumpulan dan pendayagunaan dana zakat yang dibentuk oleh pemerintah dari tingkat pusat sampai dengan tingkat daerah, sedangkan Lembaga Amil Zakat (LAZ) merupakan Organisasi Pengelola Zakat yang dibentuk atas swadaya masyarakat.

Pada bulan Oktober 2011, buku PSAK 109 telah terbit dan dinikmati oleh kita semua. Itu artinya bahwa PSAK 109 telah resmi berlaku. Berlakunya PSAK 109 pada 1 Januari 2012 akan menjadi babak baru dalam perkembangan zakat di Indonesia. Semua Organisasi Pengelola Zakat (OPZ) akan dapat menjadikan PSAK 109 sebagai pedoman pengelolaan keuangan dan akuntansi, sekaligus dalam menyajikan laporan keuangan. Para akuntan publik juga dapat menjadikan PSAK 109 untuk melakukan audit atas laporan keungan Organisasi Pengelola Zakat (OPZ). Dengan semua Organisasi Pengelola Zakat (OPZ) merujuk pada PSAK 109 dalam menyajikan laporan keuangan, akan menjadi lebih mudah apabila hendak dilakukan perbandingan kinerja keuangan antar Organisasi Pengelola Zakat (OPZ). Dengan terbitnya PSAK 109, maka semakin lengkaplah pedoman pengelolaan zakat di Indonesia.

Sebagai lembaga amil zakat tingkat Nasional, Rumah Yatim Arrohman terus berupaya kebermanfaatannya dalam mengelola zakat di seluruh Indonesia. Dengan mengedepankan profesioanlisme dalam pengelolaan keuangan baik zakat, infaq maupun shadaqah. Dengan itu, penulis merasa perlu untuk melakukan penelitian pada Yayasan Rumah Yatim Arrohman dalam hal ini digunakan PSAK 109 sebagai standar perbandingan pada penyajian Laporan Keuangan Yayasan Rumah Yatim Arrohman sebagaimana diketahui bahwa Ikatan Akuntan Indonesia telah menyusun PSAK 109 tentang Akuntansi Zakat dan Infak/Shadaqah sebagai bagian dari penyempurnaan transaksi pengelolaan zakat dan infak/shadaqah pada Lembaga Keuangan Syariah. Penelitian ini bertujuan untuk mengetahui apakah laporan keuangan Yayasan Rumah Yatim Arrohman telah sesuai dengan PSAK 109 tentang Akuntansi Zakat dan Infaq/Shadaqah. 


\subsection{Tinjauan Pustaka}

\subsubsection{Organisasi Pengelola Zakat}

Organisasi Pengelola Zakat atau OPZ merupakan istilah lain dari amil zakat. Bedanya, jika amil zakat dapat dibentuk oleh perorangan, sedangkan OPZ dibentuk oleh sekelompok orang. Amil zakat adalah salah satu golongan dari tujuh golongan yang berhak menerima zakat. Amil zakat merupakan seseorang atau kelompok orang yang bertugas melaksanakan seluruh kegiatan yang berkaitan dengan urusan zakat, mulai dari proses penghimpunan, penjagaan, pemeliharaan, pendistribusian, serta proses pencatatan keluar masuknya dana zakat (Hafidhuddin, 2007). Fatwa MUI mendefinisikan amil zakat adalah Seseorang atau kelompok orang yang diangkat oleh pemerintah untuk mengelola pelaksanaan ibadah zakat, atau Seseorang atau kelompok orang yang dibentuk oleh masyarakat dan disahkan oleh pemerintah untuk mengelola pelaksanaan ibadah zakat (Majelis Ulama Indonesia, 2011).

Sedangkan Hertanto dan Teten (2001) mendefinisikan OPZ sebagai institusi yang bergerak di bidang pengelolaan dana zakat, infak, dan sedekah (Hertanto dan Teten, 2001). Pengelolaan zakat yang dimaksud di sini adalah merujuk pada apa yang didefinisikan UU nomor 23 Tahun 2011, yaitu kegiatan perencanaan, pengorganisasian, pelaksanaan, dan pengawasan terhadap pengumpulan, pendistribusian, dan pendayagunaan zakat (Pemerintah, 1999). Dalam Al-Quran Surat At Taubah:60 (Qardawi, 2004) tertulis bahwa amil zakat merupakan golongan penerima zakat ketiga setelah golongan fakir dan miskin. Asy-Syaibani berpendapat, yang termasuk kedalam kategori amil zakat adalah pencatat, petugas distribusi, penghimpun, referensi, akuntan, dan bendaharawan serta para pekerja yang sifat pekerjaannya operasional seperti supir, kurir, dan sekuriti (Hafidhuddin, 2007). Fatwa MUI menegaskan bahwa amil zakat yang tidak dibiayai oleh pemerintah berhak mendapat bagian zakat dengan batas kewajaran. Hak amil atas dana zakat tersebut digunakan untuk pembiayaan kegiatan operasional sehari-hari amil zakat dalam mengelola zakat (Majelis Ulama Indonesia, 2011).

Undang-undang nomor 38 tahun 1999 menjadi dasar bagi organisasi-organisasi pengelola zakat dalam menjalankan operasinya (Pemerintah, 1999). Seiring dengan berkembangnya zakat, maka muncul undang-undang no 23 tahun 2011 yang menyempurnakan UU no 38 tahun 1999 tersebut. Dalam undang-undang itu dijelaskan bahwa tugas pengelolaan zakat dilakukan oleh badan amil zakat dan lembaga pengelola zakat (Pemerintah, 2011). Berdasarkan undang-undang tersebut, OPZ terbagi menjadi dua jenis:

\section{- Badan Amil Zakat}

Badan Amil Zakat (BAZ) adalah lembaga yang berwenang melakukan tugas pengelolaan zakat yang dibentuk oleh pemerintah. Pengelolaan zakat nasional dilakukan oleh badan amil zakat yang dibentuk oleh pemerintah. Badan Amil Zakat dibentuk di tingkat nasional dengan nama Badan Amil Zakat Nasional (BAZNAS). Selain itu, dibentuk pula BAZ tingkat provinsi, kabupaten, dan kecamatan (Pemerintah, 2011).

\section{- Lembaga Amil Zakat}

Lembaga Amil Zakat (LAZ) adalah organisasi kemasyarakatan Islam yang dibentuk atas prakarsa masyarakat dan oleh masyarakat yang bergerak di bidang dakwah, pendidikan, sosial, dan kemaslahatan umat Islam. Lembaga Amil Zakat kemudian akan dikukuhkan dan dibina oleh pemerintah setelah memenuhi syarat yang disebutkan UU No 23 Tahun 2011 pasal 18, yaitu (1) terdaftar sebagai organisasi kemasyarakatan Islam yang mengelola bidang pendidikan, dakwah, dan sosial, (2) berbentuk lembaga berbadan hukum, (3) mendapat rekomendasi dari BAZNAS, (4) memiliki pengawas syariat, (5) memiliki kemampuan teknis, administratif, dan keuangan untuk melaksanakan kegiatannya, (6) bersifat nirlaba, (7) memiliki program untuk mendayagunakan zakat bagi kesejahteraan umat, dan (8) bersedia diaudit syariat dan keuangan secara berkala (Pemerintah, 2011). Rumah Yatim Arrohman menjadi lembaga amil zakat tingkat nasional, karena sejak didirikannya menjadi dikenal secara luas sebagai pengelola zakat, infaq/shadaqah dan 
pemberdayaan yatim piatu. Berdasarkan kriteria di atas, Rumah Yatim Arrohman digolongkan ke dalam LAZ karena dibentuk atas inisiatif masyarakat dan bukan dibentuk oleh pemerintah. Sebagai LAZ, Rumah Yatim Arrohman harus patuh terhadap UU No 23 Tahun 2011, salah satunya bersedia untuk diaudit secara berkala.

Tugas dari OPZ antara lain adalah mengumpulkan zakat, melakukan pencatatan, mengumpulkan informasi, dan mendistribusikan zakat (Qardawi, 2004). Secara garis besar tugas tersebut dikelompokkan menjadi dua bagian utama, yaitu mengumpulkan zakat dan mendistribusikan zakat. Dalam UU No 23 Tahun 2011, disebutkan bahwa tugas pokok pengelola zakat adalah mengumpulkan zakat, mendistribusikan zakat, dan mendayagunakan zakat sesuai dengan ketentuan syariat (Pemerintah, 2011). Fatwa MUI juga menyebutkan bahwa tugas pokok amil zakat adalam mengumpulkan, memelihara, mendistribusikan, dan mendayagunakan zakat (Majelis Ulama Indonesia, 2011).

Dalam menjalankan tugas OPZ di atas, semua OPZ di Indonesia yang telah diakui dan terdaftar oleh pemerintah, harus mentaati undang-undang dan peraturan yang dibuat oleh pemerintah. Salah satu aturan yang harus ditaati oleh OPZ yang telah terdaftar di pemerintah adalah bersedia untuk diaudit oleh auditor independen. Rumah Yatim Arrohman sebagai LAZ di Indonesia juga melaksanakan peraturan yang ada dan telah diaudit setiap tahun oleh auditor independen.

\subsubsection{Standar Pelaporan Lembaga Amil Zakat Berdasarkan PSAK No. 109}

Standar akuntansi ZIS yang berlaku saat ini dan digunakan oleh OPZ sebagai pedoman dalam pembukuan dan pelaporan keuangannya adalah PSAK No. 109 yang dikeluarkan oleh Ikatan Akuntan Indonesia (IAI) pada tahun 2010 (Ikatan Akuntansi Indonesia, 2011). Penerbitan PSAK ini telah mengalami proses yang cukup lama kurang lebih empat tahun dari waktu penyusunannya, dimulai dengan disusunnya Eksposure Draft-nya (ED) yang diterbitkan sejak tahun 2008. Namun, saat ini tidak semua OPZ yang ada di Indonesia dapat menerapkan PSAK No. 109. Hal tersebut karena sebagian OPZ mengalami beberapa kendala dalam penerapannya. Salah satu faktor kendalanya adalah adanya kesulitan dalam sumber daya manusia yang dimiliki OPZ (Rahman, 2015).

Akuntansi zakat yang ada dalam Pernyataan Standar Akuntansi Keuangan (PSAK) No. 109 bertujuan untuk mengatur pengakuan, pengukuran, penyajian dan pengungkapan transaksi zakat dan infak/sedekah. PSAK ini berlaku untuk amil yakni suatu organisasi/entitas pengelola zakat yang pembentukannya dan pengukuhannya diatur berdasarkan peraturan perundang-undangan yang dimaksudkan untuk mengumpulkan dan menyalurkan zakat dan infak/sedekah, bukan untuk entitas syariah yang menerima dan menyalurkan ZIS tetapi bukan kegiatan utamanya (Rahman, 2015). Entitas tersebut mengacu pada PSAK No. 101: Penyajian Laporan Keuangan Syariah (Friyanti, 2016).

Amil yang menerima dan menyalurkan zakat / sedekah, yang selanjutnya disebut "amil", merupakan organisasi pengelola zakat yang pembentukannya dimaksudkan untuk mengumpulkan dan menyalurkan zakat dan infak/sedekah. Pernyataan ini wajib diterapkan oleh amil yang mendapat izin dari regulator. Amil yang tidak memiliki izin dari regulator dapat menerapkan pernyataan ini (Friyanti, 2016).

Dalam PSAK No. 109 tentang akuntansi zakat, infaq/sedekah terdapat beberapa komponen laporan keuangan yang harus dibuat oleh amil secara lengkap yang terdiri dari:

\section{- Laporan Posisi Keuangan}

Amil menyajikan dalam laporan posisi keuangan dengan memperhatikan ketentuan dalam SAK yang relevan mencakup beberapa hal, tetapi tidak terbatas pada pos-pos berkut:
○ Aset.
○ Liabilities
- Saldo Dana 
- Dana Laporan Perubahan

Amil menyajikan laporan perubahan dana zakat, dan infak/sedekah, dan dana amil. Penyajian laporan perubahan dana mencakup, tetapi tidak terbatas pada pos-pos berikut:

- Dana Zakat

○ Dana Infak/sedekah

- Dana Amil.

- Laporan Perubahan Aset Kelolaan

Amil menyajikan laporan perubahan aset kelolaan yang mencakup, tetapi tidak terbatas pada:

○ Aset kelolaan yang termasuk aset lancar dan akumulasi penyisihan.

- Aset kelolaan yang termasuk aset tidak lancar dan akumulasi penyusutan.

- Penambahan dan pengurangan.

- Saldo awal.

○ Saldo akhir.

- Laporan Arus Kas

Amil menyajikan laporan arus kas sesuai dengan PSAK No. 2: Laporan Arus Kas dan SAK lain yang berlaku.

- Catatan atas Laporan Keuangan

Amil menyajikan catatan atas laporan keuangan sesuai dengan PSAK No. 101: Penyajian laporan keuangan Syariah dan SAK lain yang berlaku. PSAK ini berlaku untuk tahun buku yang dimulai pada atau setelah tanggal 1 Januari 2012. Penerapan dini diperkenankan.

\section{METODE}

Objek dalam artikel ini adalah Yayasan Rumah Yatim Arrohman. Yayasan Rumah Yatim Arrohman sendiri adalah Lembaga Amil Zakat Nasional (LAZNAS) milik masyarakat indonesia yang berkhidmat mengangkat harkat sosial kemanusiaan yatim dhuafa dengan dana ZISWAF (Zakat, Infaq, Shadaqah, Wakaf) serta dana lainnya yang halal dan legal, dari perorangan, kelompok, perusahaan/lembaga.

Jenis data yang digunakan adalah data sekunder. Data sekunder adalah data yang diperoleh peneliti dari sumber yang sudah ada, seperti gambaran umum perusahaan, struktur organisasi dan sebagainya. Data yang diperoleh dari literatur-literatur yang berkaitan dengan masalah penelitian seperti buku teks tentang lembaga amil zakat. Sumber data yang diperoleh berasal dari dokumendokumen yang relevan dengan masalah pokok yang telah dikemukakan pada latar belakang masalah, seperti laporan keuangan (Laporan Keuangan Yayasan Rumah Yatim Arrohman, 2016), pencatatan akuntansi, serta kebijakan akuntansi zakat dan infak/sedekah perusahaan.

Metode analisis yang digunakan dalam penelitian ini adalah deksriptif kualitatif yakni mendeskripsikan atau menggambarkan keadaan objek yang sesungguhnya untuk mengetahui dan menganalisis tentang penerapan akuntansi zakat, infak/shadaqah pada objek penelitian kemudian disamakan dengan standar yang ada. Penelitian ini mendeskripsikan penerapan akuntansi zakat dan infak/shadaqah pada Yayasan Rumah Yatim Arrohman. Data yang dikumpulkan dianalisis dengan membandingkan akuntansi zakat dan infak /shadaqah yang diterapkan pada Yayasan Rumah Yatim Arrohman dengan PSAK No. 109. 
Yayasan Rumah Yatim Arrohman menggunakan PSAK 109 sebagai pedoman dalam membuat laporan keuangan. Dalam laporan keuangan Yayasan Rumah Yatim Arrohman ini telah di Audit sebelumnya (Laporan Keuangan Yayasan Rumah Yatim Arrohman, 2016). Analisis komponen Laporan Keuangan Yayasan Rumah Yatim Arrohman diuraikan sebagai berikut:

\subsection{Laporan Posisi Keuangan}

Di dalam Laporan Posisi Keuangan, Yayasan Rumah Yatim Arrohman menyajikan posisi aset, kewajiban, dan saldo dana per tanggal laporan. Penyajian aset dan kewajiban tidak terlalu berbeda dengan laporan posisi keuangan organisasi lainnya. Namun, pada laporan posisi keuangan OPZ bagian modal diganti dengan saldo dana. Saldo dana mencerminkan aktiva kelolaan (baik lancar maupun tidak lancar) yang dimiliki oleh OPZ tahunan Yayasan Rumah Yatim Arrohman adalah sebagai berikut:

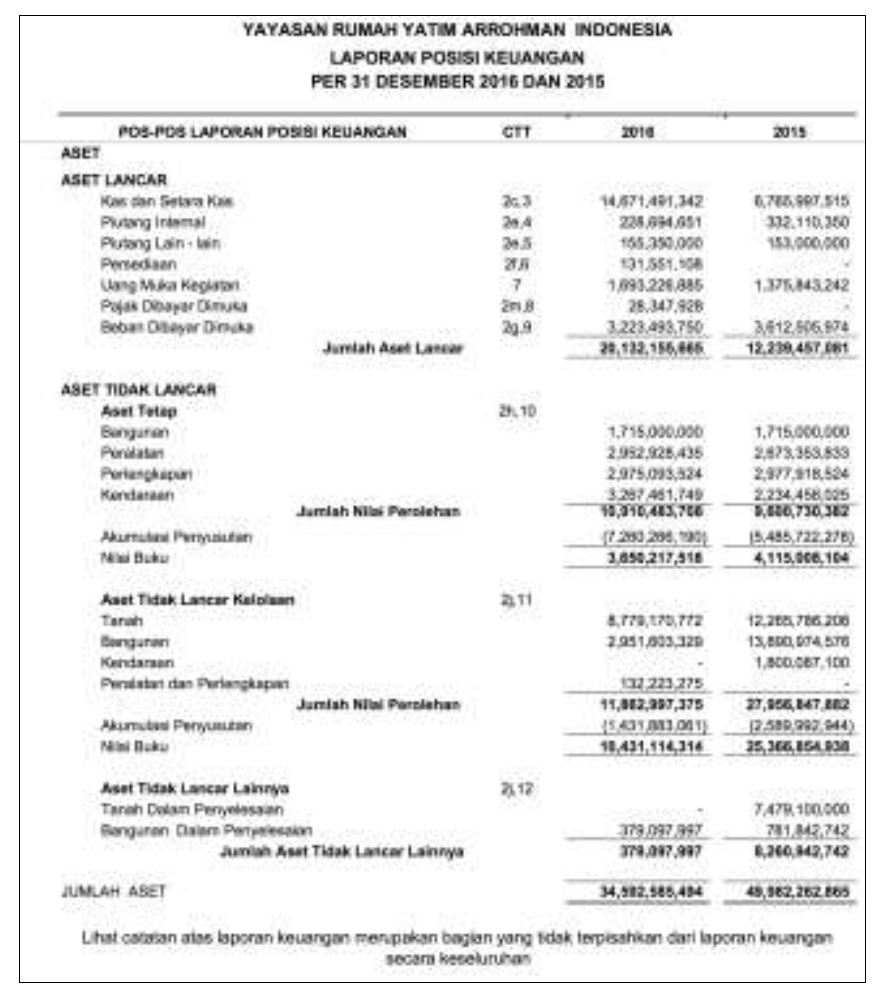

Gambar 1. Laporan Posisi Keuangan 


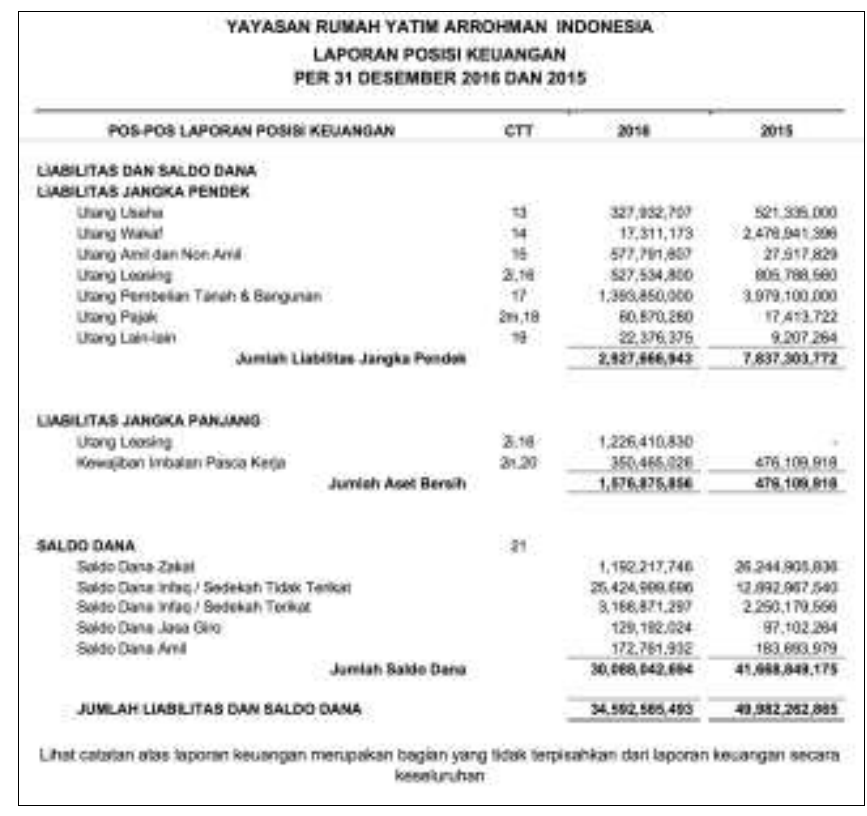

Gambar 2. Laporan Posisi Keuangan

Dalam format laporan Yayasan Rumah Yatim Arrohman secara umum. Dalam format ini, terdapat dua kolom berbeda yaitu tahun 2015 dan tahun 2016. Penyajian ini memudahkan pembaca laporan keuangan untuk melihat seberapa besar posisi keuangan dari tahun 2015-2016. Setelah dianalisa, format laporan posisi keuangan Yayasan Rumah Yatim Arrohman sebagai laporan utama sudah sesuai dengan yang diatur pada lampiran PSAK 109. Dilihat dari laporan keuangan Yayasan Rumah Yatim Arrohman merinci saldo dana yang terdiri dari saldo dana zakat, infak/sedekah, dan saldo dana amil. Biaya yang masih harus dibayar termasuk dalam kewajiban lancar. Kewajiban employment benefit masuk dalam kewajiban jangka panjang.

Dalam penyajian laporan posisi keuangan, Yayasan Rumah Yatim Arrohman menyajikan akun-akun aktiva sesuai dengan urutan likuiditasnya, dari yang paling likuid yaitu kas dan setara kas, sampai yang paling tidak likuid, yaitu aset tetap. Untuk kewajiban, akun disajikan dari kewajiban jangka pendek ke kewajiban jangka panjang. Hal ini sudah sesuai dengan contoh format laporan posisi keuangan pada PSAK 109. Aktiva tetap disajikan dalam nilai buku, penjelasan dari aktiva tetap dan akumulasi penyusutannya bisa dibaca dari catatan atas laporan keuangan. Saldo dana dalam PSAK 109 adalah selisih dari aktiva dan kewajiban. Saldo dana terdiri dari dana zakat, dana infak/sedekah, dan dana amil. Pengklasifikasian saldo dana tersebut dilakukan sesuai dengan sumber penerimaan dana pada OPZ. Dalam laporan ini, disajikan saldo dana dari dana zakat, infak/sedekah, dan dana amil. Hal ini telah sesuai dengan PSAK 109.

\subsection{Laporan Perubahan Dana}

Laporan Perubahan Dana adalah laporan yang menggambarkan kinerja organisasi, yang meliputi penerimaan dan penggunaan dana pada suatu periode tertentu. Oleh karena itu Yayasan Rumah Yatim Arrohman membuat Laporan Perubahan Dana sesuai format yang tertera di lampiran PSAK 109. Karena secara tidak langsung laporan perubahan dana Yayasan Rumah Yatim Arrohman sudah lengkap dan jelas dari tahun 2015-2016. 


\begin{tabular}{|c|c|c|c|}
\hline \multicolumn{4}{|c|}{ 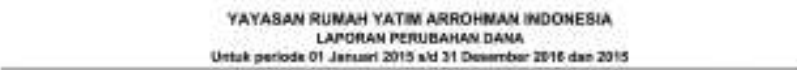 } \\
\hline XETERANGAK & cा & pangensin & $\begin{array}{c}\text { ans } \\
\text { PRuplani }\end{array}$ \\
\hline 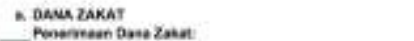 & $212 z$ & & \\
\hline Pronoweas Zera & & 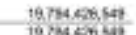 & $7.194212 \times 1$ \\
\hline \multicolumn{2}{|l|}{ Proponem Dera zibat } & $10.704,2,0,540$ & $10,034212 \times 1$ \\
\hline \multirow{2}{*}{\multicolumn{2}{|c|}{ Moniturinturi }} & - & $4342,139,72$ \\
\hline & & & 5ser sou, tes \\
\hline \multicolumn{2}{|l|}{ 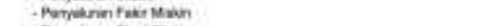 } & $18.482,001,568$ & \\
\hline \multicolumn{2}{|l|}{ 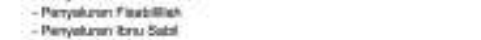 } & Z2.032,001,733 & 270312000 \\
\hline \multirow{2}{*}{\multicolumn{2}{|c|}{ 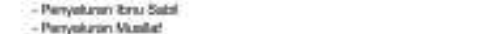 }} & 5,405000 & $n \geq 0,000$ \\
\hline & & $2 \times 2,000$ & \\
\hline \multirow{2}{*}{\multicolumn{2}{|c|}{ 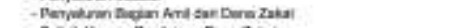 }} & 2473004008 & $2142 \mathrm{ml}, \mathrm{Ws}$ \\
\hline & & 200,250 & \\
\hline \multicolumn{2}{|l|}{ 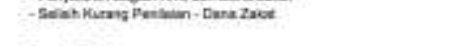 } & S4672114,5] & Retgesoges \\
\hline \multirow{2}{*}{\multicolumn{2}{|c|}{ Sarpencoura }} & 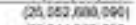 & 247900563 \\
\hline & & 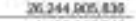 & $2774900+6$ \\
\hline \multicolumn{2}{|l|}{ Saboseater } & $1,172 \times 1+, 244$ & 2824400563 \\
\hline \multirow{3}{*}{ 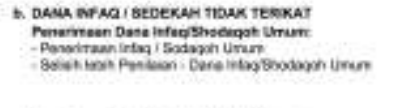 } & 2123 & & \\
\hline & & 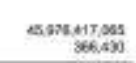 & 20701,205 san \\
\hline & & esmeresiass & $30 \times 1200004$ \\
\hline \multicolumn{4}{|l|}{ 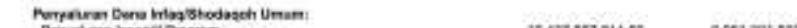 } \\
\hline \multirow{2}{*}{\multicolumn{2}{|c|}{ 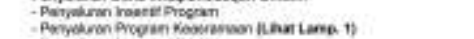 }} & 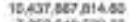 & aceisat,803 \\
\hline & & 7800046093 & akc129:4a? \\
\hline \multicolumn{2}{|l|}{ 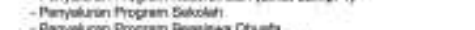 } & 102171450 & 2006,03010 \\
\hline \multicolumn{2}{|l|}{ 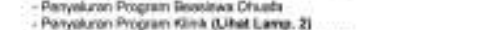 } & 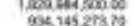 & 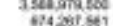 \\
\hline \multicolumn{2}{|l|}{ 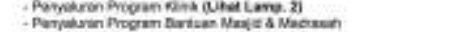 } & $110,028,00002$ & 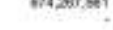 \\
\hline \multicolumn{2}{|l|}{ 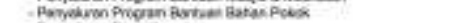 } & 23220000 & : \\
\hline \multicolumn{2}{|l|}{ 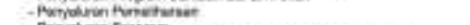 } & $251,1004360 a 2$ & \\
\hline \multirow{2}{*}{\multicolumn{2}{|c|}{ 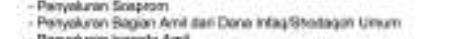 }} & $1002,001,10006$ & $2,706,757,46$ \\
\hline & & 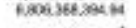 & 6.) 64,194944 \\
\hline \multicolumn{2}{|l|}{ 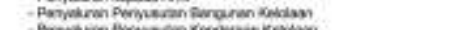 } & 100 t $103,000 \mathrm{Bi}$ & : \\
\hline \multicolumn{2}{|l|}{ 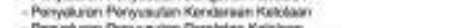 } & $800,864,0006.75$ & $421,712,524$ \\
\hline \multicolumn{2}{|l|}{ 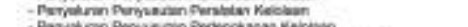 } & $24,2026 \pi 624$ & \\
\hline \multirow{2}{*}{\multicolumn{2}{|c|}{ 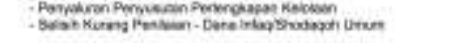 }} & 2969083053 & . \\
\hline & & Anse, 147,00 & \\
\hline \multirow{2}{*}{\multicolumn{2}{|c|}{ Surtacotet }} & $53.444,751,340$ & $32,900,200,300$ \\
\hline & & $12,922,002,793$ & $052,915,224$ \\
\hline \multicolumn{2}{|l|}{ sessa ined } & $12 \operatorname{ang}, 000,943$ & 12040,000248 \\
\hline \multicolumn{2}{|l|}{ Sovata hatio } & $8.424000,025$ & $12 \mathrm{mm12}, 967,540$ \\
\hline
\end{tabular}

Gambar 3. Laporan Perubahan Dana

\begin{tabular}{|c|c|c|c|}
\hline \multicolumn{4}{|c|}{ 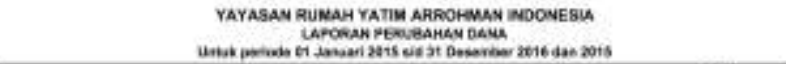 } \\
\hline KETERANGAN & $\mathrm{ctr}$ & $\begin{array}{c}2016 \\
\text { Mupute }\end{array}$ & $\begin{array}{c}\text { To1s } \\
\text { Mapiay }\end{array}$ \\
\hline \multirow{6}{*}{ 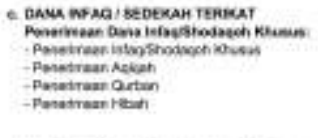 } & ase. & & \\
\hline & & 6.79572, 266 & $2.225 \mathrm{kn} 80 \mathrm{~s}$ \\
\hline & & $45 x 20100$ & $25 a e s 000$ \\
\hline & & 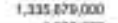 & $\ln 406,2 \pi 4$ \\
\hline & & 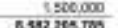 & \\
\hline & & $0,582.285,700$ & $2,408258,00 \pi$ \\
\hline \multicolumn{4}{|l|}{ 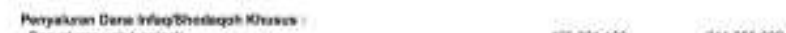 } \\
\hline 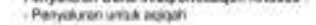 & & $450,221,130$ & 2at $\cos 300$ \\
\hline Apriparen unu astes & & t.940400000 & 1.953.236.378 \\
\hline 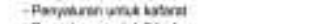 & & 202001 & - \\
\hline 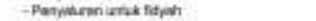 & & Ate $12+5000$ & $=$ \\
\hline -Parpaturin artal ractex & & M1, 262,400 & 1900,000 \\
\hline - Ratpituren unk progem & & 4,7423 manis & $\mathbf{\infty 1 , 0 2 3 , 4 0 4}$ \\
\hline \multirow{3}{*}{ 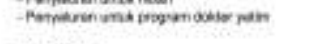 } & & & 30913,900 \\
\hline & & sos 400000 & son.212.985 \\
\hline & & T, ocssit,aes & $2.452101,06$ \\
\hline \multirow{3}{*}{ 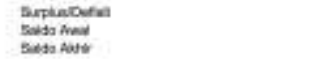 } & & Maven,tat & $1,047,461,35$ \\
\hline & & 2.252 .170950 & 1,202717906 \\
\hline & & $3,981,01,201$ & $2,232110,586$ \\
\hline \multirow{3}{*}{ 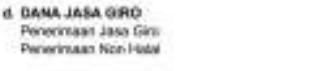 } & ass & & \\
\hline & & Danesiost & satespat \\
\hline & & 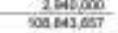 & onesos \\
\hline \multirow{3}{*}{ 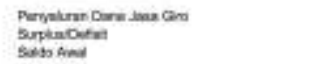 } & & motsoan & $74+10000$ \\
\hline & & 21000,100 & 2.28201 \\
\hline & & 1100204 & 97514009 \\
\hline Rado Autrir & & 520.102 .028 & $37,160,254$ \\
\hline
\end{tabular}

Gambar 4. Laporan Perubahan Dana

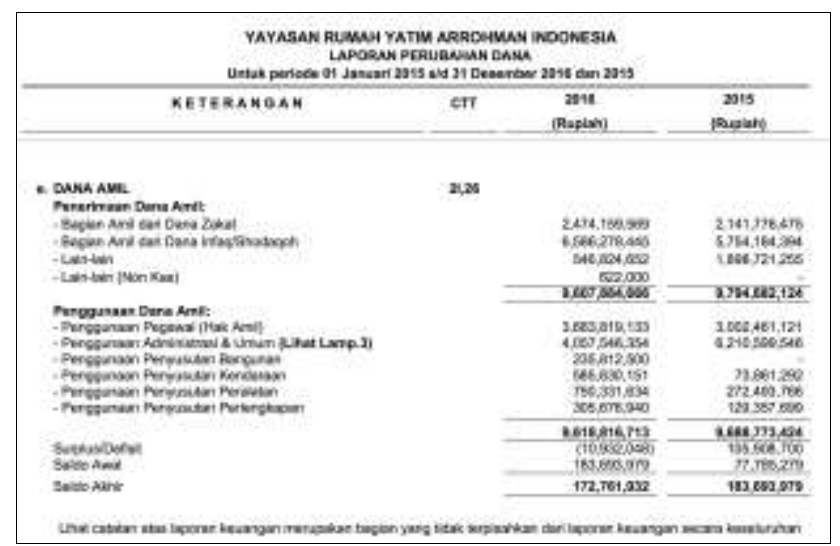

Gambar 5. Laporan Perubahan Dana 


\subsection{Laporan Arus Kas}

Laporan arus kas adalah laporan yang menggambarkan arus kas masuk dan keluar pada suatu periode tertentu. Tujuannya adalah untuk menyajikan informasi mengenai penerimaan dan pengeluaran kas organisasi pada suatu periode tertentu. Laporan arus kas Yayasan Rumah Yatim Arrohman disusun dengan metode langsung (direct method) dengan mengelompokkan arus kas dalam aktivitas operasi, investasi dan pendanaan. Dalam pembuatan laporan arus kas, Yayasan Rumah Yatim Arrohman berpedoman kepada PSAK 2 tentang laporan arus kas, sehingga laporan arus kas Yayasan Rumah Yatim Arrohman sudah sesuai dengan PSAK 109.

\subsection{Catatan Atas Laporan Keuangan}

Catatan Atas Laporan Keuangan merupakan rincian atau penjelasan detail dari laporan keuangan sebelumnya yang dapat bersifat kuantitatif dan kualitatif. Dalam Catatan Atas Laporan Keuangan Yayasan Rumah Yatim Arrohman diterangkan berbagai catatan dan penjelasan dari laporan keuangan yang disajikan. Catatan Atas Laporan Keuangan adalah bagian yang tidak terpisahkan dari laporan keuangan Yayasan Rumah Yatim Arrohman secara utuh. Catatan Atas Laporan Keuangan juga merupakan salah satu bentuk pengungkapan Yayasan Rumah Yatim Arrohman terhadap kebijakan, aktivitas, dan keuangannya. Dari analisa penulis, Laporan yang dibuat oleh Yayasan Rumah Yatim Arrohman sudah cukup informative dan bisa menjelaskan dari laporan secara keseluruhan.

\subsection{Analisis Penerapan PSAK 109 pada Yayasan Rumah Yatim Arrohman}

Pada pencatatan akuntansi dan pelaporan Yayasan Rumah Yatim Arrohman telah menerapkan aturan-aturan yang terdapat dalam PSAK 109. Dalam menyusun pelaporan keuangan, Yayasan Rumah Yatim Arrohman mengacu pada PSAK 109. Laporan keuangan Yayasan Rumah Yatim Arrohman diterbitkan tahunan. Laporan tahunan mengungkapkan laporan keuangan lebih lengkap yang terdiri dari laporan posisikeuangan, laporan perubahan dana, laporan perubahan aset kelolaan, laporan aruskas, dan catatan atas laporan keuangan. Berikut menjelaskan penerapan PSAK 109 tentang pengungkapan:

Tabel. 1 Penerapan PSAK 109 pada Yayasan Rumah Yatim Arrohman

\begin{tabular}{|c|c|c|}
\hline PSAK 109 & Pelaksanaan pada Yayasan & Kesesuaian \\
\hline \multicolumn{3}{|c|}{ ZAKAT } \\
\hline $\begin{array}{l}\text { Amil menyajikan dana zakat, dana infak, } \\
\text { dan dana amil secara terpisah dalam } \\
\text { laporan posisi keuangan. }\end{array}$ & $\begin{array}{l}\text { Dalam laporan Yayasan Rumah Yatim } \\
\text { Arrohman yang khusus LAZ, laporan } \\
\text { posisi keuangan menyajikan dana } \\
\text { zakat, dana infak, dan dana amil secara } \\
\text { terpisah. }\end{array}$ & Sesuai \\
\hline $\begin{array}{l}\text { Penggunaan dana zakat/infak dalam } \\
\text { bentuk asset kelolaan. Diungkapkan } \\
\text { jumlah persentase terhadap seluruh } \\
\text { penyaluran dana zakat dan alasannya. }\end{array}$ & $\begin{array}{l}\text { Mengenai aset kelolaan dapat dilihat di } \\
\text { dalam laporan keuangan tahunan } \\
\text { Yayasan Rumah Yatim Arrohman }\end{array}$ & Sesuai \\
\hline $\begin{array}{l}\text { Hubungan pihak-pihak berelasi antara amil } \\
\text { dan mustahik yang meliputi sifat } \\
\text { hubungan, jumlah dan jenis aset yang } \\
\text { disalurkan, dan presentase dari setiap aset } \\
\text { yang disalurkan tersebut dari total } \\
\text { penyaluran zakat selama periode. }\end{array}$ & $\begin{array}{l}\text { Yayasan Rumah Yatim Arrohman } \\
\text { menjelaskan di CALK mengenai } \\
\text { jejaring yang digunakan untuk } \\
\text { menyalurkan zakat, jumlah dan jenis. }\end{array}$ & Sesuai \\
\hline \multicolumn{3}{|c|}{ INFAK/SHADAQAH } \\
\hline $\begin{array}{l}\text { Kebijakan penyaluran infak/sedekah } \\
\text { seperti } \\
\text { penentuan skala prioritas penyaluran } \\
\text { infak/sedekah dan penerima infak/sedekah }\end{array}$ & $\begin{array}{l}\text { Dalam CALK diungkapkan skala } \\
\text { prioritas penyaluran dan penerimaan } \\
\text { infak/sedekah. }\end{array}$ & Sesuai \\
\hline $\begin{array}{l}\text { Kebijakan penyaluran infak dan sedekah } \\
\text { untuk amil dan nonamil, seperti persentase } \\
\text { pembagian, }\end{array}$ & $\begin{array}{l}\text { Dalam CALK diungkapkan mengenai } \\
\text { kebijakan penyaluran untuk amil dan } \\
\text { nonamil, persentase pembagiannya. }\end{array}$ & Sesuai \\
\hline
\end{tabular}


Pelaporan keuangan Yayasan Rumah Yatim Arrohman sudah sesuai dengan apa yang telah digariskan dalam PSAK 109. Menurut penulis, pembuatan laporan keuangan Yayasan Rumah Yatim Arrohman yang sekarang sudah baik dan informatif bagi pembaca laporan keuangan. Namun, bila dilihat dari kepatuhan terhadap PSAK 109, masih perlu diperbaiki.

\section{KESIMPULAN}

Berdasarkan hasil penelitian, dapat disimpulkan bahwa Yayasan Rumah Yatim Arrohman sangat merasa dimudahkan dengan adanya PSAK No. 109 dan sudah sesuai dalam menerapkan Pernyataan Standar Akuntansi Keuangan (PSAK) No. 109. Berdasarkan pernyataan bahwa laporan keuangan Yayasan Rumah Yatim Arrohman telah sesuai dengan Pernyataan Standar Akuntansi Keuangan (PSAK) No. 109, berikut secara rinci kesimpulan dari penelitian ini: Pertama, Pernyataan Standar Akuntansi Keuangan (PSAK) No. 109 adalah standar akuntansi yang memang dibuat untuk laporan keuangan lembaga amil zakat dan memang sudah seharusnya diterapkan oleh lembaga amil zakat pada laporan keuangannya. Kedua, Pada proses penerimaan dan penyaluran dana zakat dan dana infak/sedekah Yayasan Rumah Yatim Arrohman mencatat sebagai penambah dan pengurang dana zakat pada saat zakat diterima dan dikeluarkan. Ketiga, Dalam penyajian laporan keuangannya Yayasan Rumah Yatim Arrohman menyajiankan setiap transaksi yang dilakukan secara terpisah berdasarkan sumber dan peruntukannya. Terakhir, Pada keseluruhan laporan keuangan Yayasan Rumah Yatim Arrohman telah sesuai dengan Pernyataan Standar Akuntansi Keuangan (PSAK) No. 109 dari sisi pengakuan, pengukuran, penyajian dan pengungkapan secara keseluruhan dan telah sesuai dengan ketentuan Pernyataan Standar Akuntansi Keuangan (PSAK) No. 109. Hanya saja dalam pengakuan, Yayasan Rumah Yatim Arrohman tidak melaporkan dana non halal.

\section{DAFTAR PUSTAKA}

Al-Qur'an Al-Karim

Friyanti, E. Y. (2016). Laporan Keuangan Lembaga Kemanusiaan Merujuk Pada PSAK 109 (Sebagai Kajian untuk Laporan Keuangan Lembaga Nirlaba Syariah). AL-INTAJ. Vol. 2(2). hh. 133142.

Hafidhuddin, Didin. (2007). Panduan Praktis tentang Zakat, Infak, dan Sedekah. Jakarta: Gema Insani.

Hertanto, W. dan Teten, K. (2001). Akuntansi dan Manajemen Keuangan untuk Organisasi Pengelola Zakat. Cetakan pertama, Bandung: Ass-syaamil press dan grafika.

Ikatan Akuntan Indonesia. (2011). Pernyataan Standar Akuntansi Keuangan No.109 Akuntansi Zakat dan Infak/Sedekah. Jakarta: IAI.

Laporan Keuangan Yayasan Rumah Yatim Arrohman 2016. Diambil dari http://www.rumahyatim.org/web/?/laporan-keuangan/

Majelis Ulama Indonesia. (2011). Fatwa No 8 Tentang Amil Zakat. Jakarta.

Pemerintah, I.R. (1999). UU No. 38 tentang Pengelolaan Zakat. Jakarta: Forum Zakat.

Pemerintah, I.R. (2011). UU No. 23 tentang Pengelolaan Zakat. Jakarta: Forum Zakat.

Qardawi, Yusuf. (2004). Hukum Zakat. Jakarta: Lintera Antar Nusa. 
Rahman, Taufik. (2015). Akuntansi Zakat, Infak dan Sedekah (PSAK 109): Upaya Peningkatan Transparansi dan Akuntabilitas Organisasi Pengelola Zakat (OPZ). Jurnal Muqtasid. Vol. 6(1). hh. 141-164. 